\title{
Özel Eğitim ve Rehabilitasyon Merkezi Kurumlarının Beden Eğitimi Öğretmeni İstihdamına Bakış Açısı
}

\author{
Sibel NALBANT ${ }^{*}$, Nazan IZGAR ${ }^{2}$ \\ İstanbul Gedik Üniversitesi Spor Bilimleri Fakültesi, ORCID iD: 0000-0002-3481-6337 \\ ${ }^{2}$ Istanbul İl Milli Ĕ̈itim Müdürlüğ̈̈
}

$\ddot{O} \mathbf{z}$

Bu araştırma özel eğitim ve rehabilitasyon kurumu sahiplerinin gözünden beden eğitimi öğretmeni istihdamı gerekliliği ve konuyla ilgili sorunları belirlemek amacıyla yapılmıştır. Nitel araştırma veri toplama tekniklerinden bireysel görüşme tekniği kullanılmış ve İstanbul ili Pendik ilçesinde bulunan 1 kadın 3 erkek olmak üzere toplam 4 kurum sahibi ile görüşme yapılmıştır. Araştırma verileri yarı yapılandırılmış görüşme tekniği ile toplanmış, geçerlik ve güvenirlik sağlanması için çeşitleme (triangulation) tercih edilmiștir. Elde edilen bulgulara göre katılımcılar, özel gereksinimli çocukların spor aktivitelerine ihtiyacı olduğunu belirtmiş ve özel eğitim ve rehabilitasyon merkezlerinde istihdam edilecek olan beden eğitimi öğretmenlerinin alanla ilgili deneyimlerinin olmasinin önemli olduğunu vurgulamışlardır. Araştırmanın sonuçları, kurum sahiplerinin özel eğitim ve rehabilitasyon merkezlerinde beden eğitimi öğretmenlerinin istihdam edilebilmesi için, yasal düzenlemelerin olması gerektiğini ve ancak bu yasal düzenleme yapıldığı takdirde beden eğitimi öğretmeni istihdam edebileceklerini ortaya koymaktadır. Bu sonuçlara bağlı olarak, ancak Milli Eğitim Bakanlığına bağlı özel eğitim kurumlarında engelliler için spor alanında deneyimli beden eğitimi öğretmeni bulundurma zorunluluğu konusunda yasal düzenleme yapılır ise beden eğitimi öğretmenlerine mesleki tanınırlık sağlanacak ve özel eğitim alanında Orijinal Makale Yayın Bilgisi Gönderi Tarihi:03.05.2018 Kabul Tarihi: 29.06 .2018 Online Yayın Tarihi: 30.06.2018

DOI: $10.30769 /$ usbd.420781 hizmet sunma olanağına erişilecektir.

\section{Perspective of Special Education and Rehabilitation Institutions on Physical Education Teacher Employment}

\begin{abstract}
The study was conducted in order to determine the necessity of physical education teacher employment and the problems related to the subject in the eyes of private education and rehabilitation institution owners. In this research individual interviewing technique, one of the qualitative research data gathering techniques, has been used and 4 institution owners 1 female and 3 male- have been interviewed. The research data has been gathered by semistructured interview technique and triangulation has been preferred to provide validity and reliability. The participants have noted that special-needs children need sports activities and emphasized that it is important that physical education teachers, who are to be employed in Special-needs Education and Rehabilitation Centers, have experience in the field. As a striking outcome, the research results indicate that there must be legal regulations so that institution owners can recruit physical education teachers in Special Needs Education and Rehabilitation Centers, and provided that these regulations are made, they can employ physical education teachers. According to the research findings all participants reported that physical education is important for special needs individuals. In addition the participants have noted necessary legal arrangements must be made and physical education teachers who expert in this should be employed in the field of special education. Depending on these results, it can be thought that it is a prerequisite for solving the problem of making legal regulations about the necessity of providing physical education teachers for disabled people in special education institutions affiliated to the Ministry of National Education.
\end{abstract}

Original Article

Article Info

Received: 03.05.2018

Accepted: 29.06 .2018

Online Published: 30.06.2018

Anahtar kelimeler:
Özel Gereksinimli Birey,

Beden Eğitimi,

Istihdam

"Sorumlu Yazar: Sibel NALBANT, E-Posta: sibel.nalbant@gedik.edu.tr 


\section{GíRiş}

Eğitim sisteminin en önemli amacı; hak temelli yaklaşımla, tüm çocukların gelişim süreçlerindeki olası sorunlarını çözmek ve gereksinim duyulan alanlarda eğitim hizmeti sunmaktır. Bu sistemin içinde yer alan özel eğitimin amacı ise; herhangi bir nedenle normal eğitim süreçlerinden yararlanamayan bireylere eğitimde firsat eşitliği sağlamaktır. Bunu gerçekleştirmek için özel eğitim kurumlarının eğitim programlarının, çok yönlü gelişimi destekler nitelikte olması gerektiği düşünülmektedir.

Çocuğun doğal ihtiyacı olan hareket ve oyun isteği, okulda beden eğitimi derslerinin önemini artırmaktadır. Çünkü eğitim sistemi gereği öğrenciler ev yaşantısından daha çok okulda zaman geçirmektedirler. Günümüz eğitim öğretim kurumlarında okutulan derslerle, öğrencilerde geliştirilmek istenen, bilgi ve beceriler gibi bilişsel davranışlardaki değişikliklerin yanında; psikomotor gelişim ve duyuşsal davranışlarda vardır (Demirci ve Topbaş Demirci, 2014). Özel eğitime gereksinim duyan öğrenciler söz konusu olduğunda ise uygun beden eğitimi ve spor uygulamaları ile kişinin kendine yeten bir birey olarak yaşamın devamlılığını sağlama ve toplumsal uyum açısından beden eğitimi ve spor uygulamalarının ne kadar önem taşıdığı bilinmektedir (MEB, 2012). Özel eğitime ihtiyaç duyulan çocuklarda yapılacak olan aktiviteler için uzun vadeli hedefler ele alındığında; engelli bireylerde olumlu benlik kavramı, sosyal yeterlilik, motor becerilerde gelişim, fiziksel ve motor uygunluk, serbest zaman becerileri, gerilimi giderme, oyun becerileri ve yaratıcı ifadeleri geliştirme amaçlanmıştır. Bu doğrultuda öğrencilerin oyun ve fiziki etkinliklere istekle, düzenli katılım alışkanlığı geliştirmeleri önemlidir. Özel eğitime gereksinim duyan çocuklar doğumdan sonraki süreçte engeli olmayan diğer çocuklarla aynı gelişim özelliklerini göstermeseler de her iki grubunda içsel enerjisinin boşaltılması, genel gelişiminin sağlaması ve deneyim kazanılması bakımından ortak noktası oyundur. Bunun yanısıra özel eğitime gereksinim duyan çocuklar aktif ve sağlıklı bir yaşam biçimi için gerekli olan bilgi, beceri ve tutumları kendiliğinden geliştiremezler. $\mathrm{Bu}$ gelişim ancak öğrenme süreci içerisinde mümkün olabilmektedir (Reindal, 2010). Bu nedenle öğrenme, çocukluk döneminde başlamalı ve bunun için gerekli koşullar sağlanmalıdır. Eğitimcilerin üzerine düşen görev ise, öğrenme ortamını hazırlamak, engelli öğrencilerin günlük bedensel etkinliği hayat boyu alışkanlık hâline getirmeleri ve sağlıklı bir yaşam biçimi kazanmalarını sağlamaktır (Demirci ve Topbaş Demirci, 2014).

Özel gereksinimli bireyler erken dönemde özel eğitim kurumlarında eğitime başlamakta ve uzun süreli olarak bu kurumlarda farklı gelişimsel alanlarda eğitim almaktadırlar. Özel eğitim alanında yetişmiş özel eğitim öğretmeni ve ekipte farklı görevlerle anılan diğer profesyoneller de doğrudan eğitim sürecinin içine girmektedir (Reindal, 2008). Bu durum, özel eğitim hizmetlerini düzenleyen 573 Sayılı kanun Hükmünde Kararnamede "özel eğitim sınıf, okul ve kurumlarına öğretmenler; özel eğitim programını bitirmiş olanlardan atanır” şeklinde ifade edilmektedir. Ayrıca ilgili yönetmelikte sınıf öğretmenliğinin esas olduğu okullarda; özel eğitim öğretmenleri, atölye ve branş öğretmenleri ile birlikte derse girer. Resim, müzik, beden eğitimi gibi özel beceri gerektiren dersler branş öğretmenleri, kurstan geçerek branşlaşmış sınıf öğretmenleri veya ek branşı uygun olan özel eğitim öğretmenleri tarafından verilir (MEB, 2005). Ancak özel eğitim çok disiplinli yaklaşım gerektiren bir alandır. Bu nedenle beden eğitimi öğretmenlerinin bu tür kurumlarda işbirlikçi yaklaşımla görev alması özel eğitime katkı sağlayacağı düşünülmektedir. Motor becerilerin en hızlı 
geliştiği dönem erken çocukluk dönemidir. Bu nedenle özel eğitim gerektiren bireylerin erken çocukluk döneminden itibaren beden eğitimi öğretmenleri tarafından uygulanacak yoğunlaştırılmış beden eğitimi ve spor uygulamalarına gereksinimleri vardır.

Özel eğitime ihtiyaç duyan çocuklarda planlanacak beden eğitimi aktiviteleri psikomotor, duyuşsal ve bilişsel alanlarda gelişimi sağlayacak nitelikte olmalıdır. Psikomotor alan çocuğun sosyal ve duygusal gelişimi üzerinde önemli rol oynayan motor becerilerin kazanılmasında önemli bir değer taşımaktadır. Fiziksel aktivite ve beden eğitimine bizzat katılan birey de motor gelişimle ile ilgili olarak; fiziksel ve motor uygunluk düzeylerinin gelişmesi, beden yapısının temel bileşenlerinin gelişiminin sağlanması, koordinasyon kazanılması, kas dayanıklılığı ve kas kuvvetin oluşturulması, bedenin denge ve esneklik gibi özelliklerinin kazandırılması, algısal motor fonksiyonların pekiştirilmesi, kinestetik ve dokunsal olarak algılamanın ve beraberinde algısal motor yeteneklerin gelişimine olanak sağlaması izlenmektedir. Böylece engelli birey, günlük yaşamında ve spor etkinliklerinde ince, kaba motor becerileri kolaylıkla yapılabilmektedir (Özer. 2001).

Fiziksel aktiviteye bizzat katılan birey de duyuşsal alanla ile ilgili olarak; yaşamla başa çıkma yeteneği ve kendi hakkında bilgi edinimini, hareket yeteneğini ve vücut beğenisini arttırma, çevreye uyum sağlamayı öğrenme, değiştiremeyeceği sınırlılıklarını kabul etme ve böylece kendini gerçekleştirmeye doğru adımlar atma özelliklerinin geliştiği izlenmektedir (Özer, 2001). Ülkemizde düzenlenen birtakım "sporlar ve engellilerde spor konulu çalıştayların sonucu olarak özel gereksinimlilerde spor" konusunda ülke ihtiyaçları doğrultusunda tavsiye kararları alınmaktadır. Spor Şurası (2008) "Engelliler ve Spor" komisyonunun raporunda; "Milli Eğitim Bakanlığına bağlı özel eğitim kurumlarında engelliler için spor alanında eğitim almış beden eğitimi öğretmeni bulundurma zorunluluğu getirilmesi için yasal düzenlemeler yapılmalıdır." şeklinde ülke ihtiyaçları doğrultusunda tavsiye kararları alınmıştır. 1.Ulusal Engelli Bireyler İçin Fiziksel Aktivite Çalıştayı Raporunda; (Özer ve Şahin, 2009) Üniversitelerin lisans eğitimi veren beden eğitimi öğretmenliği, spor yöneticiliği, antrenörlük, rekreasyon, spor bilimleri bölümü mezunlarının, eğitim alanı olarak özel eğitim ve rehabilitasyon merkezlerinde de istihdam edilmesi gerekliliği konusunda tavsiye kararı alınmıştır.

Pendik Engelsiz Spor Çalıştayı Raporunda, Engelli Sporcular ve Öğrenciler için Eğitmen Yetiştirilmesi başlığı altında; Özel Eğitimi ve Rehabilitasyon merkezlerinde beden eğitimi öğretmeninin görevlendirilmesi, ilgili ders modülünün eklenmesi ve 20 yaş üstü okul yaşamı sonlanmış engelli bireyler için özel eğitim ve rehabilitasyon merkezlerinde spor programlarının açılması doğrultusunda tavsiye kararı alınmıştır. Ancak alınan bu kararlar yürürlülüğe eklenmesi için gerekli yasal düzenlemelerin yapılması gerekmektedir.

Bilindiği gibi üniversitelerin lisans eğitimi veren beden eğitimi öğretmenliği, spor yöneticiliği, antrenörlük, rekreasyon, spor bilimleri bölümü mezunları istihdam arayışı içindedir. Diğer taraftan nüfusun \%12,29'unun engelli olduğu Türkiye'de önemli sayıda engelliler için beden eğitimi öğretmenine ihtiyaç duyulmaktadır (Konar ve Yıldıran, 2012).

Ülkemizde Özel Öğretim Kurumları Genel Müdürlüğü’ne bağlı, özel eğitim ilköğretim okullarında 4138 ve özel eğitim ve rehabilitasyon merkezlerinde 181665 kişi özel eğitim hizmetlerinden yararlanmaktadır. Özel eğitim ve rehabilitasyon merkezlerine devam eden özel gereksinimli bireylerin, bir "hak" olarak fiziksel aktivite ve spor ihtiyaçlarının giderilmesi ve sportif faaliyetlere yönlendirilebilmesi için yeterli sayıda özel gereksinimi olan 
bireyler için beden eğitimi ve spor alanında uzmanlaşmış eğitmenlerin özel eğitim ve rehabilitasyon merkezlerinde istihdam edilmeleri oldukça önemlidir. Özel gereksinimi olan bireyler için beden eğitimi ve spor alanında uzmanlaşmış eğitmen istihdam eden özel eğitim ve rehabilitasyon merkezi sayısının Türkiye ihtiyaçlarını karşılayacak sayıda olmadığı açıkça ortadadır. Çok disiplinli bir yaklaşımla özel eğitim planlaması yapması beklenen özel eğitim ve rehabilitasyon merkezi sahiplerinin konuyla ilgili görüşlerinin önemli olduğu noktasından hareketle bu araştırmaya gereksinim duyulmuştur. Bu gereksinim doğrultusunda araştırmanın amacı, özel eğitim ve rehabilitasyon kurumu sahiplerinin gözünden beden eğitimi öğretmeni istihdamı gerekliliği ve bu yolda karşılaşılan sorunların neler olduğunun belirlenmesidir. $\mathrm{Bu}$ genel amaç doğrultusunda da sorulara yanıt aranmıştır.

\section{YÖNTEM}

Araştırma bir arama, öğrenme, bilinmeyeni bilinir hale getirilme çabasıdır. Nitel araştırma; "gözlem, görüşme ve doküman analizi gibi nitel veri toplama yöntemlerinin kullanıldığı, algıların ve olayların doğal ortamda gerçekçi ve bütüncül bir biçimde ortaya konmasına yönelik nitel sürecin izlendiği araştırma” olarak tanımlamaktadır (Karasar, 2000).

Niteliksel araştırmalarda veriler rakamlardan ziyade sözlü ifadeler şeklindedir. Kimi araştırmacı, araştırmasını bir okulda yapar ve sınıfa girip öğretmeni gözlemleyip kaydeder. Kimisi ise sınıfta görüntü kaydı yapıp analiz eder. Kimisi ise bunların hepsini birlikte kullanır. Niteliksel araştırmalarda veriler görüşmeler, görüşmelerin dökümleri, saha notları, görüntü ve ses teyp kayıtları aracılığıyla toplanır. Yapılan kayıtların ortamdaki kişilerle birlikte izlenmesi araştırmacının kendi yorumuyla o kişilerin yorumunu karşılaştırmasına olanak sağlar. Kayıtların defalarca izlenmesi/dinlenmesiyle araştırmacı ortamda gerçekleşen olayların kalıplarını keşfeder. Ses ve görüntü kayıtlarıyla insan beyninin kayıt ettikleri birleştirildiğinde kapsamlı veriler elde edilmiş olur. Görüntü kayıtlarındaki sözel olmayan iletişim davranışlarının yakalanması ve defalarca izlenerek anlamlandırılması söz konusudur (Uzuner, 2005).

$\mathrm{Bu}$ araştırmada özel eğitim ve rehabilitasyon kurumu sahiplerinin gözünden beden eğitimi öğretmeni istihdamı gerekliliğini belirlemek amacıyla, nitel araştırma veri toplama tekniklerinden bireysel görüşme tekniği, geçerlik ve güvenirlik sağlanması için ise çeşitleme (triangulation) tercih edilmiştir.

Verilerin analizinde Gömülü Teori yaklaşımı dikkate alınmıştır. Bu yaklaşımın en önemli özelliği araştırma sonucunda ulaşılan teorinin verilerden elde edilmesidir. Veriler araştırma sürecinde sistematik olarak toplanır ve analiz edilir. Araştırmacı veri toplama ve analiz süreci sırasında verilerin içine gömülü olan yeni kavram veya teoriyi ortaya çıkarır (Uzuner, 2005).

\section{Katılımcilar}

Araştırmanın evrenini, İstanbul ili Pendik ilçesinde bulunan özel eğitim ve rehabilitasyon merkezi kurum sahipleri oluşturmaktadır. Araştırmanın örneklemini ise görüşmeleri kabul eden dört (4) özel eğitim ve rehabilitasyon merkezi kurum sahibinden oluşmuştur. Katılımcıların isimlerini korumak amacıyla her birine araştırmacılar tarafından farklı isimler verilmiştir. Araştırmaya katılan 4 özel eğitim ve rehabilitasyon merkezi kurum sahibi 1' i kadın, 3' ü ise erkektir. Katılımcıların eğitim durumları 2' si üniversite terk, 2' si üniversite 
mezunudur. Mesleki deneyimlerine bakıldığında ise; en az 5 yıl, en çok 16 yıl mesleki deneyimlerinin olduğu görülmektedir.

\section{Veri Toplama Tekniği}

Nitel araştırmalarda verilerin toplanmasında kullanılabilecek dört temel yöntem vardır. Bunlar, odak grup görüşmesi, gözlem, görüşme ve doküman incelemedir. Görüşme tekniği, nitel araştırmada temel veri toplama araçlarındandır (Fırat, 2014). Aynı zamanda başkalarını anlamak için kullanılan en güçlü yöntemlerdendir ve özellikle sosyolojide en sık kullanılan araştırma yöntemlerinden biridir (Yıldırım ve Şimşek, 2005).

Görüşme tekniği, beceri, duyarlılık, yoğunlaşma, bireyler arası anlayış, öngörü, zihinsel uyanıklık ve disiplin gibi pek çok boyutu kapsaması açılarından, hem sanat hem de bilimdir (Yıldırım ve Şimşek, 2005). Görüşme yönteminin avantajları, incelenen konuyla ilgili olan davranışların gerçek nedenleri ve yapısal belirleyicileri hakkında daha sağlıklı bilgi alma olanağı sağlaması, katılımcıya konuların ve başlıkların ana hatlarını belirlemesinde ortam yaratması, daha derinlemesine ve detaylı bilgi sağlamasıdır. Ayrıca bu teknik, katılımcının görüşlerinin daha iyi anlaşılması, konuyla ilgili inançların, deneyimlerin ve kullanılan terminolojinin ortaya çıkarılması ve yapısal görüşmelerde ortaya çıkmayacak olan beklenmedik konuların anlaşılmasına ortam yaratmaktadır. Dezavantajları ise, görüşmelerin başarılı ve verimli olabilmesi için gerekli olan konuya vakıf, araştırma ekibinin bir parçası olan, yalnızca mekanik olarak soru soran görüşmecilerin değil, yüksek beceriye sahip, iyi eğitilmiş görüşmecilerin bulunmasının her zaman mümkün olamamasıdır. Görüşmeci öncelikle güven vermelidir. Katılımcıyı anlamak istediğini ve bunun önemini anlatabilmelidir. Görüşmeci iyi bir dinleyici olmalı, dinlerken çeşitli geri besleme yöntemleri ile katılımcıyı cesaretlendirmelidir (Yıldırım ve Şimşek, 2005; Sevencan ve Çilingiroğlu, 2007).

\section{Veri Toplama Süreci}

Niteliksel bir araştırma çerçevesinde gerçekleştirilen bu çalışmada, Özel Eğitim ve Rehabilitasyon Kurumu Sahiplerinin Gözünden Beden Eğitimi Öğretmeni İstihdam1 gerekliliği ve sorunlarına ilişkin görüş ve önerilerinin neler olduğunu belirlemek amaciyla bireysel görüşme tekniğinden yararlanılmıştır. Araştırma verilerinin toplanması yarı yapılandırılmış görüşme formu ve kişisel bilgi formu ile gerçekleştirilmiştir. Oluşturulan görüşme soruları alanında uzman iki öğretim üyesi ve araştırmacının kendisi tarafından oluşturulmuştur. Görüşme formunu oluşturma aşamasında ön uygulama yapılmıştır. Ön uygulamada iki kurum sahibiyle görüşülmüştür. Ön uygulamaya katılan kurum sahipleri araştırmaya dahil edilmemiştir. Ön uygulama yapıldıktan sonra görüşme formunun geçerliliğini sağlamak amacıyla uzman görüşüne sunulmuştur. Görüşme formundaki sorular ve ön uygulamanın ses kaydı uzamanlar tarafından dinlenerek soruların araştırma konusuyla ilgili ve araştırmanın amacına uygun olup olmadığı açısından tekrar değerlendirilmiş ve görüşme formu son haline getirilmiştir.

Katılımcılardan görüşme randevusu talep edilirken, görüşmelerin anket şeklinde olmadığ1, görüşme sırasında yapılacak ses kayıtlarının sadece araştırmacı tarafından kullanılacağı ve verilerin yorumlanmasında kod adı verilerek kendilerinin gizliliğinin sağlanacağ belirtilmiştir. Ayrıca en etkin görüşmenin yapılabilmesi için görüşme yapılacak yeri ve zamanı kendilerinin belirlenmeleri istenmiştir. Görüşmeler yarı yapılandırılmış görüşme formu rehberliğinde ses kaydı yapılarak gerçekleştirilmiştir. Görüşme belirtilen şu esaslara dayalı olarak gerçekleştirilmiştir; (1) Kurum kurucuları tarafından sorunun cevabı tam 
verilmez ise "Eklemek istediğiniz başka bir şey var mı?” şeklinde soru yöneltilmesi; (2) Sorulan soruyla beraber bir başka sorunun cevabı verilmiş ise o sorunun tekrar sorulmaması; (3) Görüşme sırasında görüşmecinin anlamadığı soru olup açıklık getirmesini ister ise, görüşmeciyi yönlendirmeyecek şekilde açıklamalar yapılması; (4) Görüşmeciyle görüşme sırasında ismi veya siz diye hitap edilmesi (5) Görüşmeler samimi bir şekilde sürdürülmesi.

\section{İstatiksel Analiz}

Nitel veri analizi, araştırmacının verileri düzenlediği, analiz birimlerine ayırdığı, sentezlediği, biçimleri (pattern) ortaya çıkardığı, önemli değişkenleri keşfettiği ve hangi bilgileri rapora yansitacağına karar verdiği bir süreçtir (Özdemir, 2017). Diğer bir deyişle nitel analiz yapan araştırmacı, alandan toplamış olduğu verilerden hareket ederek bu veriler içerisinde saklı duran bilgiyi keşfetmeye ve ortaya çıkartmaya çabalamaktadır.

Gömülü teori, Glaser ve Strauss tarafından 1967 yılında geliştirilmiş, verilerin sistematik bir şekilde bir araya getirilerek ve analiz edilerek, yeni olguların keşfedilmesi yöntemidir (Duman, 2010). Elde edilen bilgiler karmaşık ve yoğun olduğundan, araştırmanın kavramsal zenginliğini arttırmaktadır. Nitel bir araştırma yöntemi olan gömülü teori yaklaşımında veriler genellikle görüşme, gözlem, günlükler gibi yazılı materyaller ya da bu metotların birleşiminden oluşur. Gömülü teori yaklaşımında bu metotların karmasının kullanımı önerilmektedir (Duman, 2010).

Araştırma verilerinin analizi Strauss ve Corbin tarafından geliştirilen tematik analiz yöntemi ile yapılmıştır Strauss ve Corbin (1990), nitel veri analizi sürecini "kodlama" olarak tanımlamaktadır. Araştırmacı, kodlama sürecine, verilerin kavramlaştırılması ile başlamaktadır. Kavramsallaştırma, bir gözlemden, bir cümleden ya da bir paragraftan hareket ederek ilgili olay, düşünce ya da olguya isim verme sürecidir. $\mathrm{Bu}$ süreçte araştırmac1 araştırma konusu olan olay ve olgulara yönelik kimi sorular sormaktadır. Örneğin, "bu nedir? Neyi temsil eder?" gibi. Ardından cevaplara dayalı olarak olay ve olgular karşılaştırılır ve benzer nitelikteki olaylar aynı isimler altında kavramsallaştırılır. Bu sürecin sonunda araştırmacı oldukça fazla miktarda kavram elde etmiş olur. Bu aşamada araştırmacı birbiri ile ilişkili kavramları gruplandırmak suretiyle çeşitli kategoriler (temalar) keşfeder. Böylece analiz edilecek birim sayısı da azaltılmış olur. Kavramsallaştırma aşamasında olduğu gibi kategorilere de isimler verilir. Ancak kategorilere verilen isimler kavramlara verilen isimlerden daha soyut düzeyde kalır. Ardından bu kategorilere ait özellikler ve alt boyutlar tanımlanır. Strauss ve Corbin tarafından geliştirilen veri analiz süreci de daha önce tartışılmış olduğu gibi tümevarımcı yaklaşımla kuram inşa etmeyi amaçlamaktadır (Özdemir, 2017).

Araştırma verilerinin analizine başlamadan önce, katılımcıların görüşmelere vermiş oldukları cevaplar ses kayıt cihazından bilgisayar ortamında yazıya geçirilerek deşifre edilmiştir. Yapılan dokümanların tamamı tek tek okunarak değerlendirilmiştir. Yapılan değerlendirmeler sonucunda, her bir soruya verilen yanıtlar yazılmıştır. Her bir soruya farklı sözcüklerle ifade edilmiş yanıtlar belirlenerek kodlama anahtarı (temalar) oluşturacak cevaplar oluşturulmuştur.

Verilerin analizinde gömülü teori kapsamında açık ve eksensel kodlama aşamaları uygulanmıştır. Açık kodlama safhasında özel eğitim ve rehabilitasyon merkezi kurum sahipleri ile yapılan görüşmelerde her soruya vermiş oldukları yanıtlar ayrıntılı bir biçimde incelenerek araştırmanın amacına uygun olduğu düşünülen ifadeler belirlenmiştir. Bu ifadeler bir sözcük veya sözcük grubuyla kodlanmıştır (Ticari amaçlı, fizyoterapi ile yapılıyor, istek, sosyal etkinlik, yırtma-yapıştırma, spor gibi). Kodlanan bir veri aynı özelliklere sahip olan 
başka bir veri ile aynı kodu almıştır. Örneğin, görüşmelerden elde edilen verilerde yer alan ve sosyal etkinlik ve yırtma-yapıştırma içeren bütün açıklamalar "Beden eğitimi yerine sosyal etkinlik yaptırmak" olarak kodlanmıştır. Aynı tema altında birleşen olgular bir kategoriyi oluşturmuştur. Buna göre, bu araştırmada sosyal etkinlik, yırtma-yapıştırma gibi kodlar beden eğitimi yerine sosyal etkinlik yaptırmak ile ilişkilendirildiğinden bu kategori altında incelenmişlerdir. Böylelikle, verilerden yola çıkılarak oluşturulan kodlar arasındaki ilişkiler ortaya konulmuştur. Eksensel kodlama sürecinde ise açık kodlama sonucunda ortaya çıkan ana kategorilerin alt kategoriler ve boyutları ile bağlantısı kurulmuştur (Çelik Şen ve Şahin Taşkın, 2010). Bu aşamada, açık kodlama sonucu ortaya çıkan kategorilerin birbirleriyle olan ilişkileri ortaya konulmuştur. Verilerin analizinden çıkan sonuçlar bulgular bölümünde detaylı bir şekilde incelenmiştir.

Nitel araştırmalarda geçerlik ve güvenirliği artırmak için yapılan kısa yoldan denetleme stratejisi, (1) Veriler kopyaland1, (2) Elde edilen kopyalar, orijinal kaydetmeye ve düzeltmeye karşı yeniden kontrol edildi, (3) Çözümleme kriterleri kullanılarak veriler kodlandı, (4) Karar verme süreçlerinin tüm özelikleri ortaya kondu, (5) Her bir bölümle ilgili toplananlar tekrar çözümlendi ve kodlamalar kontrol edildi, (6) Elde edilen sonuçlar görüşmecilerden elde edilen orijinal metinlerle karşılaştırıldı, (7) Elde edilen veriler ve ulaşılan yorumların sebepleri alanda uzman olan ve farklı alanlarda çalışan araştırmacılarla gözden geçirildi, (8) Uzman olan ve olmayan araştırmacılar vasıtasıyla elde edilen bilginin türü ve miktarı incelendi.

Toplanan verilerin güvenirliğinin belirlenmesi amacıyla, görüşmelerin dökümünün yapıldığı görüşme formları görüşme yapanın kendisi, alanında uzman öğretim üyeleri tarafından, birbirlerinden bağımsız olarak kodlama anahtarlarının belirlenmesi ile yöntemine başvurulmuştur. Görüşülen kurum müdürlerinin görüşlerine uygun bulunan seçeneğin görüşme kodlama anahtarına işaretlenmesi yapılmıştır.

Araştırmacıların yaptığı kodlamaların tutarlılığını belirlemek amacıyla, kodlamanın yapıldığı görüşme kodlama anahtarlarında yer alan her bir sorunun cevabı tek tek ele alınarak karşılaştırılmıştır. Araştırmacı ve uzman kişilerin, katılımcıların vermiş olduğu cevabı aynı işaretlemiş ise kodlamalar kabul edilmiştir. Ancak, katılımcıların vermiş olduğu cevapları farklı işaretlenmiş ise tekrar farklı kodlamalara bakılarak tek bir kod altında toplanmıştır. Araştırmacı ve uzman kişiler verilen cevaplarda hiçbirini kodlamamış ise kodlamalar arasında bu cevaplara yer verilmemiştir. Kodlamalarda geçerlilik ve güvenirlilik kodlamalar arasında görüş birliği sağlanarak yapılmıştır.

\section{Verilerin Çözümlenmesi}

Görüşme kodlama tamamlandıktan sonra araştırmacı ve uzman kişiler arası kodlama anahtarındaki her bir maddeye ilişkin yanıtlara bakılarak soruya yanıt veren kişi sayısı bulunmuştur 


\section{BULGULAR}

Araştırma verilerinin analizi Strauss ve Corbin(1990) tarafından geliştirilen tematik analiz yöntemi ile yapılmış ve Tablo 1 de belirtilen temalar oluşturulmuştur.

Tablo 1. Yarı Yapılandırılmş Mülakat Sonucunda Öne Çıkan Temalar

Temalar

Ticari amaçlı kurum açılması

Kaba ve ince motor hareketlerin fizyoterapist yerine beden eğitimci yapabilir 2

Beden eğitimi ihtiyacının diğer öğretmenlerle giderilmesi, beden eğitimi öğretmeni yerine 2 okul öncesi öğretmeninin tercih edilmesi

Fiziksel aktivite ile beden eğitimi kavramının doğru bilinememesi 2

Beden eğitimi öğretmeni istihdam etmeye yönelik isteklilik 3

Beden eğitimi yerine sosyal etkinlik yaptırmak 3

Özel gereksinimi olan çocukların spor ile desteklenmemesi 2

Beden eğitimi hocası çalıştırabilmek için imza yetkisi olması gerektiği 2

Beden eğitimi öğretmeni çalıştırabilmek için rehabilitasyonun bütçesinin yetmemesi 4

Engelli çocuklarla çalışmaya yönelik duygusal bağlılık 1

Eğitim programında bedensel gelişimin göz ardı edilmesi 2

Beden eğitimi öğretmeni için devletin destek vermemesi 4

Sözleşmeli olarak beden eğitimi öğretmeninin alınmasında öğrenciye karşı sorumluluk 3 oluşması

Beden eğitimi öğretmenlerinin mesleki yetersizliği 3

$\begin{array}{ll}\text { Ticari amaçlı kurum açılması } & 2\end{array}$

Tematik analiz yöntemi ile elde edilen temalar "beden eğitimi öğretmeni istihdamında bir bariyer olarak yasal düzenlemeler", "kurum sahiplerinin yetersiz bilgiye sahip olması" ve "beden eğitimi öğretmeni istihdamına ilişkin bireye özgü görüşler" olmak üzere üç ayrı bulgu olarak derlenmiş ve her bir bulguyu oluşturan temalar aşağıda detaylı olarak açıklanmıştır.

\section{Beden eğitimi öğretmeni istihdamında bir bariyer olarak yasal düzenlemeler}

Özel eğitim kurumlarına beden eğitimi öğretmenlerinin istihdam edilebilmesi için imza yetkilerinin olması gerektiğini ve bunun için de yasal düzenlemelerin yapılması ve kurum sahiplerin bu yasal çerçeve içerisinde beden eğitimi öğretmeni çalıştırabilecekleri ve en önemlisi kurumların özel gereksinimli çocukların oyun temelli beden eğitimi ve spor aktivitelerine ihtiyacı olduğu görüşüne ulaşılmaktadır.

\subsection{Beden eğitimi öğretmeni yerine okul öncesi öğretmeninin tercih edilmesi}

Kurum sahiplerin kendi imkânları ile beden eğitimi ihtiyaçlarını karşılanmasına yönelik tutumlarının olduğu fakat, okul öncesi öğretmenleri ile eğitimi sağlayıp aynı zamanda imza yetkisi avantajı olması düşünülmektedir. Bu görüşe aşağıda yer verilmiştir. 
“Okul öncesi öğretmeni koyarım girer çıkarlar, girer çıkarlar aynı zamanda imzasını da atar oraya, sistem bu, otistik bir çocuğu düşün, enerjiyi düşün, o enerjiyi nereden atacaksın veya diğer zihinsel engelli çocuklardaki sporla yapılabilecek bazı gelişmelerin olması gerekiyor. Ben bunun farkındayım ama çalıştırmadım beden eğitimi ögretmeni. ”(Ayça Hanım)

Yöneticilerin, beden eğitiminin engelli çocukların gelişimleri üzerinde etkili oldukları konusunda hem fikir oldukları fakat bu ihtiyacın diğer ögretmenler tarafından giderilebileceği görüşünü belirtmeleri de dikkat çekmektedir. Bu görüşe aşağıda yer verilmiştir.

"Beden eğitimi kadrosu yok çünkü, olmadı̆̆ içinde biz ne yapıyoruz, okul öncesi ögretmenlerle dĕgerlendirebiliyoruz, ya da psikologlarla değerlendirebiliyoruz. "(Süleyman Bey)

\subsection{Beden eğitimi öğretmeni çalıştırabilmek için imza yetkisi olması gerektiği}

Beden eğitimi öğretmeni çalıştırabilmek için imza yetkisini düşündükleri ve bunu dile getirdikleri görülmektedir. Bu görüşe aşağıda yer verilmiştir.

"Beden eğitimi hocası çalıştırabilmemiz için imza yetkisi olması gerekiyor, girme hakkına sahip olması lazım, ama beden ĕgitimi öğretmenleri derse girme hakkına sahip değil “ (Cennet Hanım)

\subsection{Beden eğitimi öğretmeni istihdam edebilmek için rehabilitasyonun bütçesinin yetmemesi}

Beden eğitimi öğretmeni istihdam edebilmek için rehabilitasyon bütçesinin yeterli olmadığ belirtilmektedir. Velilerin katkıda bulunması ile eğitim faaliyetlerinin kalitesinin artabileceği de belirtilen bir digger görüştür. Bu görüşe aşağıda yer verilmiştir.

“Rehabilitasyonun bütçesi yetmiyor. " (Cennet Hanım)

"Şöyle söyleyim arkadaşlar doğru söylemiş, MEB in programında beden eğitimi yok, MEB in programları dışında ekstre ders vermiş oluyoruz. "(Süleyman Bey)

\subsection{Beden eğitimi öğretmeni için devletin destek vermemesi}

Yöneticilerin ortak görüşlerine göre beden eğitimi öğretmeni istihdam etmenin eğitim programında ve ödeneklerde karşılığının bulunmamasından dolayı yapılamadığı görülmektedir. Bu görüşe aşağıda yer verilmiştir.

"Şöyle düşünün siz burada beden ĕgitimi ögrretmeni istihdam etseniz de bu ögretmenin yapacă̆ıyla ilgili bir karşılığı olmadığı için kurum almaz.” (Ayça Hanım)

"Yani kendin getir, götür veli taşın altına elini koymuyor. Ama bizim kurumlarda bedencide çalışabilir, müzikçi de tiyatrocu da çalışabilir ihtiyaçtır. Devlet \%30 nu karşılıyor. "(Gökmen Bey) 


\subsection{Ticari amaçlı kurum açılması}

Kurum yöneticilerin eğitim kurumunun yanında bir ticari kurum işlettiklerini göz ard1 edemeyecekleri ve gelir gider dengelerini düşünmek zorunda oldukları anlaşılmaktadır. Yöneticilerin göz ardı edemedikleri bu durum onların çalıştırdıkları personel giderlerini düşünmeye itmektedir. Bu durumda yeni bir öğretmen çalıştırmak ve giderlerini karşılamak giderleri arttırmaktadır. Beden eğitimi öğretmeni çalıştırmaya olumlu baksalar da, giderlerin devlet tarafından karşılanmamasını gerekçe olarak belirtmektedirler. Bu görüşe aşağıda yer verilmiştir.

"Rehabilitasyonun bütçesi yetmiyor, bir de istihdam zorunluluğu olmayan meslek elemanı alırsak bize yük getirir, neticede burası eğitimin yanında ticaret anlayışı içinde yürüyor. “ (Cennet Hanım)

"Biz bütçe yetirmeye çalışırken bir de istihdam zorunluğu olmayan meslek adamı alırsak kurumu zarara sokarlz (Ayla hanım).

\section{Kurum sahiplerinin yetersiz bilgiye sahip olması}

Kurum sahiplerinin özel gereksinimli çocuklarda beden eğitimi ve sporun kazanımlarını bilmedikleri; fiziksel aktivitenin fizyoterapistler ve okul öncesi öğretmenleri ile tamamladıklarını dile getirirken, fiziksel aktivite ile beden eğitimi egzersizlerini aynı gördükleri saptanmıştır. Beden eğitiminden fiziksel aktivite olarak bahsetmeleri bu görüşü doğrulamaktadır.

\subsection{Kaba ve ince motor hareketlerin fizyoterapi yerine beden eğitimici ile yapılması}

Kurum sahiplerinin, fizyoterapide yapılan bazı kaba ve ince motor hareketlerin beden eğitimi ile yapılabileceği görüşüne katıldıkları görülmektedir. $\mathrm{Bu}$ açıdan bakıldığında kurum sahiplerinin beden eğitimi öğretmeni çalıştırmaya yönelik olumlu tutumlarının olduğu görülmektedir. Bu tutumu bir yönetici aşağıdaki örnekte ortaya koymaktadır.

"Alabilirsiniz ama ne yapacaksınız. Yani alan sorunu veli diyecek ki bana ha belki şu olabilir, fizyoterapide kaba-ince motor becerileri var. Orada bazı alanlarda beden eğitimi görevlendirebilirler. Şu an programı bilmiyorum yanlış bir şey söylemeyim ama şunu görmek lazım kaba-ince motoru fizyoterapiye bağlamak yerine spor olarak değiştirip bunun uygulayıcısı beden eğitimi öğretmeni olacaktır zaten."(Ayça hanım)

\subsection{Fiziksel aktivite ile beden eğitimi kavramının doğru bilinmemesi}

Katılımcıların fiziksel aktivite ile beden eğitimi egzersizlerini aynı gördükleri saptanmıştır. Beden eğitiminden fiziksel aktivite olarak bahsetmeleri bu görüşü doğrulamaktadır. $\mathrm{Bu}$ tutumu bir yönetici aşağıdaki örnekte ortaya koymaktadır.

"Şimdi fiziksel aktivite yeteri kadar yapılmıyor bizde, yaptırılamıyor. Bizim sıkıntımız aslında bu, neden yapılamıyor Meb müfredata koymamış, biz de Beden eğitimci almadık, ama sınıfcılarla yada okul öncecilerle beden fiziğini yapabiliriz” (Gökmen Bey). 


\subsection{Beden eğitimi yerine sosyal etkinlik yaptırmak}

Beden eğitiminden kazanımı, sosyal etkinliklerden kazanımla eş değer bulan katılımcıların da olduğu görülmektedir. Yapılan yırtma yapıştırma hareketlerinin bedensel hareket olarak görülmesi beden eğitiminin tanımı ve çerçevesinin yöneticilere anlatılması gerekliliğini ortaya koymaktadır. Buna ek olarak özel eğitim ve rehabilitasyon merkezlerinin eğitim programlarına, beden eğitimi ve sporun dahil edilmesi ile kazanımların kurum sahipleri tarafından daha anlaşılır olabileceği düşünülmektedir. Bu görüşe aşağıda yer verilmiştir.

"Biz ne yapıyoruz, yırtma, yapıştırma bir anlamda anaokulu konseptinde bir ĕgitim veriyoruz. Sinema seyrediyorlar, yırtma, yapıştırma yapıyorlar işte” (Gökmen Bey)

\subsection{Eğitim programında bedensel gelişimin göz ardı edilmesi}

Eğitim programlarında beden eğitimine yer verilmemesi ve bu tür eğitimlerin fizyoterapi ile tamamlandığının düşünülmesi katılımcıların ortak görüşüdür. $\mathrm{Bu}$ görüşe aşağıda yer verilmiştir.

"Spor alanı ile ilgili, bu çocukların ciddi anlamda bedensel gelişimini de göz ardı eden bir eğitimin yaklaşımı olması bazı tanılarla ilgili otizm gibi kullanılması gereken beden eğitimi öğretmeni gibi tamamen göz ardı ediliyor olması." (Ayça Hanım)

"Şimdi biz rehberlikten gelen çocuğu değerlendirirken önce bir özel ĕgitime ihtiyacı olan çocuğun öncelikle öz bakım becerisi, ikincisi dil iletişim becerisi, üçüncüsü sosyal, dördüncüsü psikomotor en son akademik becerilerdir. Yani çocuk öz bakım becerileri yapamıyor ise, yerine getiremiyor ise, karşıdaki bir insanla iletişim kuramıyor ise toplama, çıkarma, okuma, yazma ögretmenizin hiçbir faydası yok. Özel eğitimde çalışmalar düzenlenirken planlamalar yapılırken basitten karmaşığa, yakından uzağa, kolaydan zora doğru bir yol izlenir. Yani çocuk için ailesi için en öncelikle bilgi beceri hangisiyse ondan başlanır. En önemlisi günlük yaşam becerisidir." (Gökmen Bey)

\section{Beden eğitimi öğretmeni istihdamına ilişkin bireye özgü görüşler}

Kurum sahipleri beden eğitimi öğretmenlerin bu alanda bir bilgiye sahip olmadıkları ve okudukları bölümlerde buna yer verilmesi gerektiğini, bu alanda çalışan beden eğitimi öğretmenlerinin zorlandığı görüşündedirler. Kurumlara sözleşmeli beden eğitimi öğretmeni almadıklarını, neden olarak ise mevzuatta ve programda olmayan bir programı yapma durumundan dolayı çocuğun sakatlanması halinde zor durumda kalınabileceği belirtmektedirler.

\subsection{Sözleşmeli olarak beden eğitimi öğretmeninin alınmasında öğrenciye karşı sorumluluk oluşması}

Beden eğitimi olarak mevzuatta ve programda olmayan bir programı yapma durumunda çocuğun sakatlanma durumları karşısında zor durumda kalınabileceği belirtilmektedir. $\mathrm{Bu}$ durumlarda açılan soruşturma sonucunda kurumun zarar göreceği, cezalandırılacağı düşünülmektedir. Bu gibi durumlar kurum sahipleri ve idarecilerinin kendi kararlarına göre 
beden eğitimi öğretmeni çalıştırmalarını olumsuz etkilemektedir. $\mathrm{Bu}$ görüşle ilgili bir katılımcının görüşleri aşağıda verilmiştir.

"Mevzuatta ve programda olmayan bir şeyi yaparsın ha yaparsın bir şey olmaz Allah korusun çocuğun başına bir şey geldiği zaman da senin canına okurlar ben lakin var mı böyle programın yok sen niye bunu yaptın çünkü senin böyle çalışmaların yok ki, olmayan bir çalışma alanında sen niye faaliyette bulundun derler üzerine giderler, bu iş böyledir yani” (Ayça Hanım)

"Risk, çocuğu aldınız getirdiniz kurumun karşısı spor salonu bu aslında çocuğun başına bir şey olursa resmiyette ders yok size o insanı nasıl yapacaksınız bunu izah etmek çok zor, havuzda çocuğun başına bir şey geldi bunu izah edemezsiniz. Birde veli sorumluluk almiyor."(Gökmen Bey)

\subsection{Beden eğitimi öğretmenlerinin mesleki yetersizliği}

Kurum sahipleri, engelli çocuklarla herkesin çalışmak istemediğini, zorlanacaklarını bildirmişlerdir. Beden eğitimi alanında öğretmenlerin engellilerle ilgili yeterli eğitim almadıklarının ve ön yargılı olmalarının bunda etkili olduğu düşünülebilir. Beden eğitimi öğretmenlerinin aynı zamanda çocuklara zarar verme endişesi taşıyacaklarının, fazla sorumluluk gerektirdiğini düşünmelerinin bu alanda çalışmalarını etkilediği düşünülmektedir. Beden eğitimi öğretmenlerinin özel eğitim öğrencileri ile çalışmasının biraz cesaret ve başarma hissi gerektirdiği görüşü belirginleşmektedir. Bu görüşe örnek katılımcı görüşüne aşağıda yer verilmiştir.

“Özürlü çocuklarla çalışmak şöyle olabilir, belli bir dinginliği kavuşmuş, olursunuz, yani kendine gerçekleşmenin hoş bir şey olduğunu anlarsanız o zaman özel gereksinimli çocuklarla çalışırsınız. Yanı bunu böyle ayırmak lazım. Öyle herkes özürlülerle çalışamaz (Ayça Hanım)

Diğer bir görüş olarak beden eğitimi öğretmenlerinde olması gereken özellik olarak sevgi, sabır, şefkat, empati, azimden bahsedildiği görülmektedir. Bu görüşe örnek katılımcı görüşüne aşağıda yer verilmiştir.

"Başarllı bir beden eğitimi öğretmeninin iyi ĕgitmen olabilmesi için önemli olan nedir sizce? Teknoloji mi, uyum mu, sabır mı? Ben sevgi diyorum. Sevgi çok önemli, sabır, şevkat, empati, azim olacak. Hedefi vurmayan mizrak utansın."(Gökmen Bey)

\subsection{Beden eğitimi öğretmeni çalıştırmaya yönelik isteklilik}

Katılımcıların, devlet tarafından desteklendiği takdirde beden eğitimi öğretmeni çalıştırmaya yönelik istekli oldukları görüşü ağır basmaktadır. Diğer öğretmenlerin imza yetkilerinin olması da yöneticilerin bu konuda çelişkiye düşmelerine yol açmaktadır. Aynı zamanda fizyoterapistlerin yüksek maliyetleri karşısında beden eğitimi öğretmeninin istihdam edilmesi ile mali yüklerinin hafifleyeceğiyönünde görüşe sahip oldukları saptanmıştır. Kısaca beden eğitimi öğretmeni istihdamının kurum giderlerini azaltacağını düşünmektedirler. $\mathrm{Bu}$ görüşe aşağıda yer verilmiştir.

"Şöyle bir şey var bedensel engelli programı var burada fizyoterapistlerin ücretleri çok çok yüksek bedensel engelli bireysellerin modüllerinde ince motor becerisi, el-göz 
koordinasyonu, tutma, bırakma modüller var. Bu modüllere okul öncesi ögretmeni girer diyor burada da büyük bir açık var. Bu modüler var diğer branşlar verebilir dediği için kurumlarda şuna gidiyor haliyle okul önceci düşük allyor ve ona yöneliyor, tercih ediyor ama bunun yerine beden eğitimi ögretmeni dese daha farklı olur. " (Cennet Hanım)

\subsection{Engelli çocuklarla çalışmaya yönelik duygusal bağlılık}

Araştırmada bazı yöneticilerin ailede engelli çocuk bulunmasına bağlı olarak engelli çocuklara karşı duygusal bağlılıklarının olduğu, engelli çocuklara karşı manevi hislerinin yüksek olduğu görülmüştür. Bu görüşe aşağıda yer verilmiştir.

"Tabi bu benim duygusal yaklaştığım bir şeydir. Ben engelli çocuklarla çalışmak isterdim ki belki duygusallıktır, bilemiyorum çocuklart seviyorum kardeşlerim engelli olduğu için onlarla çok uğraştık onun için bu alanda yapardım." (Cennet Hanım)

\section{TARTIŞMA VE SONUÇ}

Erken dönemden başlayarak yaşamlarının önemli bir kısmını özel eğitim ve rehabilitasyon merkezlerinde geçiren özel gereksinimli çocuk ve gençlerin fiziksel aktivite ihtiyacinın giderilmesi ve sportif faaliyetlere yönlendirilebilmesi, beden eğitimi ve spor alanında eğitim almış bireylerin özel eğitim ve rehabilitasyon merkezlerinde meslek elemanı olarak, iş sahasına dahil edilmeleri ile ilişkilidir. Çok disiplinli bir yaklaşımla özel eğitim planlaması yapması beklenen özel eğitim ve rehabilitasyon merkezi sahiplerinin, beden eğitimi öğretmeni istihdamı gerekliliği konusundaki görüşlerinin önemli olduğu noktasından hareketle bu araştırmaya gereksinim duyulmuştur.

Araştırma sonucunda elde edilen temalar, özel eğitim ve rehabilitasyon kurumu sahiplerinin beden eğitimi istihdamı gerekliliği konusundaki görüşlerinin ayrıntılı bir şekilde belirlenmesini sağlamış ve bu temalardan oluşan üç temel bulgu "beden eğitimi öğretmeni istihdamında bir bariyer olarak yasal düzenlemeler, kurum sahiplerinin yetersiz bilgiye sahip olması , beden eğitimi öğretmeni istihdamına ilişkin bireye özgü görüşler" tartışmanın odak noktasını oluştumuştur.

Araştırma katılımcılarının ortak görüşü, beden eğitimi öğretmeninin özel eğitim kurumlarında istihdam edilebilmesi için "“imza yetkisinin olması gerektiği” yönündedir. Bu konuda gerekli yasal düzenlemelerin yapılması ile beden eğitimi öğretmeni istihdam edebileceklerini bildirmişlerdir. Özel gereksinimli bireylerin yaşam kalitesinin iyileştirilmesi için Amerikan Ulusal Otizm Merkezi NAC (2015) raporunda yer aldığı gibi egzersiz, fiziksel aktivite ve/veya sportif faaliyetlere katılım yolu ile çocuğun ilgi ve yetenekleri doğrultusunda sportif faaliyetlere yönlendirilmesi, çocuğun sosyal çevresinin olabildiğince genişletilebilmesini sağlamaktadır (Özer 2001; Özsoy vd., 1992). Ancak araştırmadan elde edilen "imza yetkisinin olması gerektiği, rehabilitasyon bütçesinin yetmemesi ve devletin destek vermesi" temaları, ancak gerekli yasal düzenlemeler yapıldı̆̆ takirde istenen sonuca ulaşılacağını göstermektedir.

Katılımcıların beden eğitiminden fiziksel aktivite olarak bahsetmeleri ve beden eğitimi ve spor ihtiyacının kurumda düzenlenen sosyal etkinliklerle karşılandığ1 görüşünü ortaya koyan temalar, katılımcıların konuyla ilgili "yetersiz bilgiye sahip olduklarl” bulgusunu çıkarmıştır. Ayrıca fiziksel aktivitenin fizyoterapistler ve okul öncesi öğretmenleri ile tamamlandığının bildirilmesi de bu görüşü destekler nitelikte olan bbir diğer temadır. Bu sonuca bernzer olarak Karasu ve Mutlu 'nun (2014) öğretmenlerin perspektifinden özel eğitimde yaşanan sorunlar ve çözüm önerileri konusunda yaptıkları araştırmanın sonucunda katılımcıların, akademik 
alanlarının dışındaki alanlarda da eğitime katılmalarının istenmesinin birçok problem durumu ortaya koyduğu bildirilmiştir.

Kurum sahipleri beden eğitimi öğretmenlerin özel eğitim alanında mesleki yetersizliklerinin olduğunu ve okudukları bölümlerde buna yer verilmesi gerektiği görüşünü bildirerek, bu alanda çalışan beden eğitimi öğretmenlerinin zorlandığı ifade etmişlerdir. Katılımcılardan bazıları beden eğitimi dersinin müfredatda olmamasının bu derste doğabilecek riskleri arttırarak kendilerine sorumluluk getirdiğini bu nedenle de beden eğitimi öğretmeni istihdamından kaçındıklarını bildirirken bazı katılımcılar da beden eğitimi dersi için alanında uzman kişilerin istihdamının gerekli olduğu görüşünü bildirmişlerdir. Bu sonuçlar "beden eğitimi öğretmeni istihdamına ilişkin bireye özgü görüşler" olduğunu ortaya koymuştur. Araştırmada elde edilen bu bulguyu tartışacak benzeri bir çalışmaya rastlanmamıştır.

Özel eğitimin yaygınlaştırılması sürecinde sayıları her geçen gün artan özel eğitim ve rehabilitasyon merkezleri, özel gereksinimli çocuk ve genç nüfusunun önemli oranına hizmet vermektedir. Ancak özel eğitim ve rehabilitasyon merkezlerinin sadece \% 10'unda beden eğitimi ve spor aktiviteleri program dahilinde yer almaktadır (İlhan ve Suveren, 2007). Ulusal ve uluslararası alan yazınına göre yapılan araştırmalar, özel eğitim ve rehabilitasyon merkezinde düzenli sportif eğitimlere katılan özel gereksinimli bireylerin motor beceri, sosyal beceri ve fiziksel uygunluk düzeylerinde gelişme sağlandığımı bildirmektedir

(Bayazıt vd., 2014; Beasley, 1982; Çevik ve Kabasakal, 2013; Guzman et al., 2018; İlhan, 2008; Polfuss et al., 2018; Soltani, 2018; Yanc1, 2010; Y1lmaz, 2012)

. Kanıta dayalı uygulamalarla spora katılımın katkıları belirlenmiş olmasına karşın ülkemizde özel eğitim ve rehabilitasyon merkezlerinin sadece \% 10'unda beden eğitimi ve spor aktivitelerine yer veriliyor olması konunun önemini ortaya koyan çarpıcı bir sonuçtur.

Milli Eğitim Bakanlığı, özel eğitim gerektiren bireylerin eğitim aldıkları kurumların eğitim ortamları ile ilgili olarak Özel Eğitim Hizmetleri Yönetmeliğinin 78. Maddesinde "özel eğitim hizmeti sunan kurumlar, binalarında beden eğitimi salonu gibi bölümlere de gereksinimler dahilinde yer vermek için gerekli önlemleri alır" ifadesine yer vermiştir. Tavsiye niteliğinde olan bu ifade ile kurumların bünyelerinde, özel gereksinimli bireyler için sportif alanlar yaratılması önerilse de Türkiye' deki tüm özel eğitim ve rehabilitasyon merkezlerinin sadece \% 10'unda beden eğitimi ve spor aktivitelerine yer veriliyor olması gerçeği, konunun kurum insiyatifinden öte ancak gerekli yasal düzenlemelerle çözüme ulaşabileceğini göstermektedir.

Ülkemizde araştırmanın konusuna benzer olarak yapılan bir başka çalışmaya rastlanmamış olması elde edilen bulguların yorumlanmasını sınırlamakla birlikte araştırmanın sonuçlarının ileride yapılacak olan araştırmalara katkı sağlaması yönü ile önemli olduğu düşünülmektedir. Özetle; özel eğitim ve rehabilitasyon merkezlerinde geniş oyun alanları ve çok amaçlı spor salonlarının inşa edilmesinin yanısıra engelliler için spor alanında uzmanlamış, beden eğitimi öğretmeni bulundurma zorunluluğu ile ilgili yasal düzenlemelerin yapılması şart olarak görünmekle birlikte, çoğu zamanlarını özel eğitim ve rehabilitasyon merkezlerinde sürdüren özel gereksinimli bireylerin bu yolla fiziksel aktivite, spor ve egzersiz ihtiyaçları giderilmiş olabilecektir. Ayrıca ileride yapılacak olan çalışmalarda katılımcı sayısının arttırılması ve alanında uzman kişilerin istihdamı ile sportif faaliyetler sürdüren ve sürdürmeyen kurumlar arasındaki farklılıklarının derinlemesine incelenmesi önerilmektedir. 


\section{KAYNAKLAR}

Bayazıt, B., Fil, H., Son, M., Çolak, S., Eskiyecek, C. G., \& Çolak, E. (2014). Eğitilebilir Zihinsel Engelli Kız Çocuklarda Cimnastik Çalışma Programının Denge Gelişimine Etkisinin İncelenmesi, Akademik Sosyal Araştırmalar Dergisi, 2(8), 14.

Beasley, C. R. (1982). Effects of a jogging program on cardiovascular fitness and working performance on mentally disabled adults. American Journal of Mental Deficiency, 86(6), 609-613.

Çelik-Şen, Y., ve Şahin-Taşkın, Ç. (2010). Yeni ilköğretim programının getirdiği değişiklikler: Sınıf öğretmenlerinin düşünceleri. Yüzüncü Yll Üniversitesi, Ĕ̆itim Fakültesi Dergisi, 7(2), 26-51.

Çevik, O., ve Kabasakal, K. (2013). Spor etkinliklerinin, engelli bireylerin toplumsal uyumuna ve sporla sosyalleşmelerine etkisinin incelenmesi. International Journal of Social and Economic Sciences, 3(2), 74-83.

Demirci, N., ve Toptaş Demirci, P. (2014). Özel eğitime gereksinim duyan öğrencilerin oyun ve fiziki etkinlikler dersinde elde ettikleri kazanımların incelenmesi. Inönü Üniversitesi, Beden Ĕgitimi ve Spor Bilimleri Dergisi, 1(1), 25-34.

Duman, G. (2010). Türkiye ve Amerika Birleşik Devletlerinde anasınıfına devam eden çocukların oyun davranışlarının incelenmesi: Kültürler arası bir çalışma. Yayınlanmamış doktora tezi. Gazi Üniversitesi/Eğitim Bilimleri Enstitüsü.

Fırat, M., Kabakçı Yurdakul, I., \& Ersoy, A. (2014). Bir eğitim teknolojisi araştırmasına dayalı olarak karma yöntem araştırması deneyimi. Eğitimde Nitel Araştırmalar Dergisi, 2(1), 65-86.

Guzman J., Magaña, S., Rocha, S.J., Torres, M.G., Morales, M., \& Marquez X.D. (2018). Physical activity in children with developmental disabilities: 2826 Board\# 109 June 12 . Medicine \& Science in Sports \& Exercise, 50(5S), 694.

İlhan, L. (2008). Eğitilebilir zihinsel engelli çocuklarda beden eğitimi ve sporun sosyalleşme düzeylerine etkisi. Kastamonu Eğitim Dergisi, 16(1), 315-324.

İlhan, L., ve Suveren, S. (2007). Zihinsel engelli çocuğu olan anne babaların, çocuklarının özel eğitimleri sürecinde beden eğitimi ve spor etkinliklerine yaklaşımlarının değerlendirilmesi. 9. Uluslararası Spor Bilimleri Kongresi Bildiri Kitabı, Muğla: 3-5 Kasım, s.670.

Karasar, N. (2000). Bilimsel araştırma yöntemi. (10. Basım). Ankara: Nobel, s. 22.

Karasu, T., ve Mutlu, Y. (2014). Öğretmenlerin perspektifinden özel eğitimde yaşanan sorunlar ve çözüm önerileri: Muş il örneği, Anemon Muş Alparslan Üniversitesi Sosyal Bilimler Dergisi, 2(1), 47-66.

Konar, N., ve Yıldıran, İ. (2012). Engelliler için beden eğitimi ve spor öğretmenliği: gereksinim ve bir program modeli. Selçuk Üniversitesi Beden Eğitimi ve Spor Bilim Dergisi,14 (2), 208-216 .

Koparan, Ş. (2003). Özel ihtiyaçlari olan çocuklarda spor. Uludă̆ Üniversitesi Ĕ̌itim Fakültesi Dergisi, $17(1), 14$.

Millî Eğitim Bakanlığı. (2005). Milli Eğitim Bakanlığı Özel, Özel Eğitim Okulları Çerçeve Yönetmeliği. (Sayı: 27283) Ankara: Resmî Gazete.

Millî Eğitim Bakanlığı. (2012). Özel eğitim kurumları yönetmeliği (Sayı: 28296). Ankara: Resmî Gazete.

National Autism Center. (2015). Findings and conclusions: national standards project, Phase 2. Retrieved from http://www.nationalautismcenter.org/090605-2/

Özdemir, M. (2017). Nitel veri analizi: sosyal bilimlerde yöntembilim sorunsalı üzerine bir çalişma. Eskişehir Osmangazi Üniversitesi Sosyal Bilimler Dergisi,11(1), 44-47. 
Özer, D. (2001). Engelliler İçin Beden Eğitimi ve Spor. 1. Basım. Ankara: Nobel, s.149.

Özer, D., ve Şahin, G. (2011). Engelli bireyler için fiziksel aktivite: 2009-2010 çalıştayları sonuç raporu. Gazi Beden Eğitimi ve Spor Bilimleri Dergisi, 15(2), 21-28.

Özsoy, Y., Özyürek, M., \& Eripek, S. (1992). Özel eğitime girişs. Ankara: Karatepe Yayınları, s.49.

Pendik Engelsiz Spor Çalıştayı Raporu (2014). Engelli sporcular ve öğrenciler için eğitmen yetiştirilmesi, okul içi okul sonras beden eğitimi/spor faaliyetlerine engelli bireylerin katılımının güçlendirilmesi, 16-17 Aralık, İstanbul

Polfuss, M. L., Forseth, B. M., Schoeller, D. A., \& Papanek, P. E. (2018). Accuracy of parent and child selfreported physical activity in children with special needs: A pilot study. Medicine \& Science in Sports \& Exercise, 50(5S), 451.

Reindal, M. S. (2010). What is the purpose? Reflections on inclusion and special education from a capability perspective, European Journal of Special Needs Education, 25(1),1-12.

Reindal, M. S. (2008). A social relational model of disability: a theoretical framework for special needs education?, European Journal of Special Needs Education, 23(2),135-146.

Sevencan, F., ve Çilingiroğlu, N. (2007). Sağlık alanındaki araştırmalarda kullanılan niteliksel veri toplama yöntemleri. Toplum Hekimliği Bülteni, 26(1), 25-27.

Soltani, S. (2018). Enjoyment in physical activities: What people with disabilities need to promote their health. Journal of Research in Medical Science, 23, 49.

Strauss, A., \& Corbin, J. (1990). Basics of qualitative research: Grounded theory procedures and techniques. Newbury Park, CA: Sage.

T.C. Başbakanlık, Gençlik ve Spor Genel Müdürlüğü, Spor Şurası. (2008). 26-28 Kasım / Ankara, s.250-255.

Yanc1, A. B. H. (2010). Öğretilebilir zihinsel engeli olan çocukların ruhsal ve sosyal uyumunda sportif rekreasyonun önemi. Marmara Üniversitesi, Sağllk Bilimleri Enstitüsü, Doktora Tezi, İstanbul

Yıldıım, A., ve Şimşek, H. (2005). Sosyal bilimlerde nitel araştırma yöntemleri. Ankara: Seçkin Yayıncılık.

Yılmaz, H. (2012). Eğitilebilir düzeyde zihinsel engelli öğrencilerde yapilan beden eğitimi ve spor derslerinin biyomotorik özellikleri üzerine etkisinin incelenmesi. Süleyman Demirel Üniversitesi, Sağllk Bilimleri Enstitüsü, Yüksek Lisans Tezi, Isparta. 